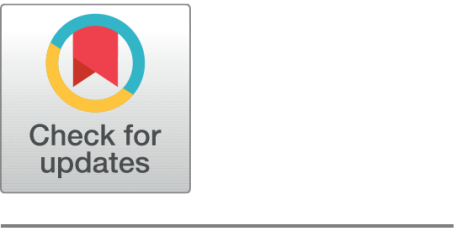

G OPEN ACCESS

Received: 08-04-2020

Accepted: 23-04-2020

Published: 18-06-2020

Editor: Dr. Natarajan Gajendran

Citation: Patel K, Patel FR (2020)

Screening of biosurfactant producing yeasts isolated from mangrove ecosystem of Surat region of Gujarat, India. Indian Journal of Science and Technology 13(20): 1927-1934. https://doi.org/

10.17485/IJST/v13i19.204

* Corresponding author. Khyati Patel

Research Scholar, Department of Biotechnology and Microbiology, Shri M.M. Patel Institute of Sciences and Research, Kadi Sarva Vishwavidyalaya, Gandhinagar, Gujarat, India. Tel.: +91 740-531-8893

khyatimpatel22@gmail.com

Funding: None

Competing Interests: None

Copyright: (c) 2020 Patel, Patel. This is an open access article distributed under the terms of the Creative Commons Attribution License, which permits unrestricted use, distribution, and reproduction in any medium, provided the original author and source are credited.

Published By Indian Society for Education and Environment (iSee)

\section{Screening of biosurfactant producing yeasts isolated from mangrove ecosystem of Surat region of Gujarat, India}

\author{
Khyati Patel ${ }^{1 *}$, Falguni R Patel ${ }^{\mathbf{2}}$ \\ 1 Research Scholar, Department of Biotechnology and Microbiology, Shri M.M. Patel Institute \\ of Sciences and Research, Kadi Sarva Vishwavidyalaya, Gandhinagar, Gujarat, India. Tel.: +91 \\ 740-531-8893 \\ 2 Assistant Professor, Department of Biotechnology and Microbiology, Shri M.M. Patel \\ Institute of Sciences and Research, Kadi Sarva Vishwavidyalaya, Gandhinagar, Gujarat, India
}

\section{Abstract}

Background/ Objectives: Biosurfactants are extracellular surface-active compounds produced by bacteria, fungi and yeast. Interest in biosurfactant has been increasing due to their unique properties. The objective of this study is to screen for potential biosurfactant producing yeasts from mangrove areas of Gujarat in India. Methodology: The biosurfactant producing yeasts isolated from five different mangrove sites i.e. Hazira, Mandroi, Mirzapur, Kantiyajal and Machhad of Surat, Gujarat during summer season of 2015. Isolated yeasts were screened for the production of biosurfactant by Parafilm M, Oil displacement and Emulsification index method in which cottonseed oil was used as a substrate. The type of biosurfactant produced was identified by Phenol-sulfuric acid test, Biuret test and phosphate test. Findings: Total twenty four yeasts were isolated from soils of sampling sites. Yeasts were initially screened by Parafilm $M$ and oil displacement method. Out of these 24 isolate, 6 isolates namely, Ky-48, Ky-53, Ky-54, Ky-84, Ky-86 and Ky-87 showed promising biosurfactant activity. These six isolates were further subjected to secondary screening method: Emulsification test, to identify biosurfactant production. Two isolates, namely Ky-46 (emulsification index: $61.53 \%$ ) and Ky-86 (emulsification index: $46.66 \%$ ) showed maximum biosurfactant production. All six isolates showed positive result for phenol- sulfuric acid method. This indicated that the isolated biosurfactant was Glycolipid in nature. Novelty/Applications: Few mangrove yeasts have potential to produce high amount of glycolipid that can be used in food processing and detergents, healthcare and cosmetics industries.

Keywords: Biosurfactant; emulsification index; oil displacement; glycolipid 


\section{Introduction}

Surfactants are amphipathic compounds which have both hydrophilic and hydrophobic portions which can decrease surface tension between two liquids or between liquid and solid ${ }^{(1)}$. Synthetic surfactant and biosurfactant are main two groups of surfactant. Microorganisms produce extracellular biosurfactants ${ }^{(2)}$. Biosurfactants are classified into glycolipids, lipopeptides, lipoproteins, phospholipids and polymeric biosurfactants ${ }^{(3)}$.

Biosurfactants have advantages over chemical surfactant because they are biodegradable, less toxic ${ }^{(4)}$, has high selectivity and specific activity at extreme conditions ${ }^{(5-7)}$, ability to be synthesized from renewable feedstock and they show better environmental compatibility ${ }^{(8)}$. Biosurfactants are important biotechnological products with applications in many industries such as food, cosmetic and pharmaceutical industries and are cost effective at the same time ${ }^{(9,10)}$.

Biosurfactant production by using simple and low cost techniques from renewable sources become a versatile and sustainable alternative over a chemical surfactant ${ }^{(11)}$.

Among all yeasts, Candida species have been widely used for insoluble substrates fermentation and have been reported to produce biosurfactants ${ }^{(7,9,11,12)}$. Because of rigid cell walls yeasts generally produce biosurfactants in higher concentrations than bacteria ${ }^{(8,13)}$. Biosurfactant production by yeasts has been reported mainly by the Yarrowia sp., Pseudozyma sp. and Candida sp. Most of yeast species present under GRAS (generally regarded as safe) status, for example Yarrowia lipolytica, Saccharomyces cerevisiae and Kluyveromyces lactis and hence being used in food and pharmaceutical industries because they are considered as nontoxic or nonpathogenic. So, it is great advantage to use these species for biosurfactant production ${ }^{(14)}$.

Since the reports are very less in case of yeast as potent producer of biosurfactant, present study was conducted on production of biosurfactant by yeast using cottonseed oil as a low cost and easily available substrate. In this study, we focused on the screening of the potential biosurfactant producing yeast from mangrove areas of Surat region of Gujarat.

\section{Materials and Methods}

\subsection{The sampling sites}

For this study total 5 sites i.e. Hazira, Kantiyajal, Mandroi, Mirzapur and Machhad were selected across mangrove regions of Surat, Gujarat in India. Soil samples were collected from rhizospheric area of mangrove ecosystem and stored in sterile plastic bags at $4^{\circ} \mathrm{C}$ till further analysis. All sampling sites were impacted by human activities. The sampling was done during the May2015. The details of selected sampling sites are presented in Table 1.

Table 1. Location details of sampling sites of Surat region of Gujarat

\begin{tabular}{llll}
\hline Sr. No. & Name of the site & \multicolumn{2}{c}{ Location details } \\
\hline & & Longitude & Latitude \\
1 & Hazira - Industrial hazard & $21^{\circ} 08^{\prime} 356^{\prime \prime}$ & $72^{\circ} 39^{\prime} 579^{\prime \prime}$ \\
2 & Kantiyajal & $21^{\circ} 27^{\prime} 105^{\prime \prime}$ & $72^{\circ} 39^{\prime} 040^{\prime \prime}$ \\
3 & Mandroi & $21^{\circ} 25^{\prime} 712^{\prime \prime}$ & $72^{\circ} 40^{\prime} 220^{\prime \prime}$ \\
4 & Mirzapur & $21^{\circ} 22^{\prime} 385^{\prime \prime}$ & $72^{\circ} 38^{\prime} 992^{\prime \prime}$ \\
5 & Machhad - Estuarine area & $20^{\circ} 94^{\prime} 522^{\prime \prime}$ & $72^{\circ} 85^{\prime} 431^{\prime \prime}$ \\
\hline
\end{tabular}

\subsection{Media preparation}

Yeast Malt Extract Broth (YM) was made according to Van der Walt ${ }^{(15)}$, with the following composition; 0.3\% yeast extract, $0.3 \%$ malt extract, $0.5 \%$ peptone, $1 \%$ glucose; adjusted to $\mathrm{pH} 7$ with $1 \mathrm{M} \mathrm{HCl}$ supplemented with $0.025 \%$ sodium propionate and $200 \mathrm{mg}$ chloramphenicol.

\subsection{Isolation of yeast}

$200 \mathrm{mg}$ of sediment sample were directly inoculated into $25 \mathrm{ml}$ Yeast Malt Extract Broth (YM broth). YM broth flasks were incubated for $72 \mathrm{~h}$ on a shaking condition at $120 \mathrm{rpm}$ and $30^{\circ} \mathrm{C}$. The broth was serially diluted $\left(10^{0}\right.$ to $\left.10^{-6}\right)$ and aseptically inoculated on the YM plates followed by incubation for 48-72 h. Emergent colonies were purified by the serial transfer technique $^{(15)}$. The isolated yeasts colonies were collected based on their morphological characteristics. All cultures submitted to Gujarat Biotechnology Research Centre. 


\subsection{Screening of potential biosurfactant producing yeasts}

Seed cultures of yeast isolates were prepared by inoculating cells into a $100 \mathrm{ml}$ Erlenmeyer flasks containing $10 \mathrm{ml}$ of the sterile medium as described by Kitamoto et al. ${ }^{(16)}\left(0.03 \% \mathrm{KH}_{2} \mathrm{PO}_{4}, 0.03 \% \mathrm{MgSO}_{4}, 0.3 \% \mathrm{NaNO}_{3}, 0.1\right.$ Yeast extract, $4 \%$ glucose, $\mathrm{pH}$ 7). Seed culture incubated at $30^{\circ} \mathrm{C}$ in shaking condition at $120 \mathrm{rpm}$ for $72 \mathrm{~h}$. After incubation time cultures were transferred to $500 \mathrm{ml}$ flasks containing $100 \mathrm{ml}$ of the medium as described by Kitamoto et al ${ }^{(15)}$ supplemented with $4 \%$ cottonseed oil as substrate in place of $4 \%$ glucose, incubated at $30^{\circ} \mathrm{C}$ in shaking condition at $120 \mathrm{rpm}$ for 10 days. After incubation period, the Yeast culture samples were centrifuged at $10,000 \mathrm{x} g$ for $15 \mathrm{~min}$. The supernatants were taken and from that biosurfactant production was determined by 1) Parafilm M test 2) Oil displacement method 3) Emulsification index method. The cell pellet obtained was dried overnight at $100^{\circ} \mathrm{C}$ and weighed for biomass determination.

\subsubsection{Parafilm $M$ test}

$25 \mu \mathrm{l}$ aliquot of culture supernatant was dropped on a strip of parafilm $\mathrm{M}$ as a hydrophobic surface and then the diameter of the droplet was evaluated ${ }^{(17)}$. The shape of supernatant drop on the surface of parafilm $M$ was inspected after $1 \mathrm{~min}$. If the Shape of drop becomes flat, it indicates presence of biosurfactant and if the shape of drop remains in dome shape, it indicates absence of biosurfactant.

\subsubsection{Oil displacement test}

Oils displacement technique was carried out according to Morikava et al. ${ }^{(18)} .100 \mu \mathrm{l}$ of crude oil was put onto the surface of $40 \mathrm{ml}$ of distilled water in a petri plate. $10 \mu \mathrm{l}$ of the supernatant of each sample was dropped into the center of petri dish and observed for a clear zone. Oil displacement was measured as the activity of surfactant.

\section{Emulsification measurement}

Emulsification activity was measured according to the method of Satpute et al. ${ }^{(19)} .4 \mathrm{ml}$ of yeast culture supernatant and $4 \mathrm{ml}$ of kerosene was added and vortexed at high speed for $2 \mathrm{~min}$. The mixture was allowed to stand for $24 \mathrm{~h}$ prior to measurement. The emulsification activity was defined as the height of the emulsion layer divided by the total height and expressed as percentage.

$$
\text { Emulsification activity }(E 24)=\frac{\text { Height of emulsion layer }}{\text { Total height }} X 100
$$

\subsection{Chemical characterization of type of biosurfactant}

As glycolipids, lipopeptides, phospholipids are the main three types of biosurfactants, three methods are used to identify the type of biosurfactant 1) Phenol-Sulfuric test to identify for glycolipids, 2) Biuret test to identify for lipopeptides, 3) Phosphate test to identify for phospholipids ${ }^{(20)}$.

\subsubsection{Phenol-Sulfuric acid test}

$1 \mathrm{ml}$ of cell-free supernatant added in a test tube and $1 \mathrm{ml}$ of $5 \%$ phenol added. To this mixture, $2-5 \mathrm{ml}$ of concentrated sulfuric acid was added drop by drop, until orange color was developed. Development of orange color indicated the presence of glycolipids.

\subsubsection{Biuret test}

$2 \mathrm{ml}$ of cell-free supernatant was heated at $70^{\circ} \mathrm{C}$ for 10 min. 10 drops of $1 \mathrm{M} \mathrm{NaOH}$ solution added to the solution. To this mixture added $1 \%$ copper sulphate drop by drop, to observe a violet or pink ring, which indicates the presence of lipopeptides.

\subsubsection{Phosphate test}

To $2 \mathrm{ml}$ of cell-free supernatant, 10 drops of $6 \mathrm{M}$ Nitric acid was added and heated at $70^{\circ} \mathrm{C}$ for $105 \%$ ammonium molybdate was added drop by drop to mixture until yellow color is formed, and then the formation of yellow precipitate, which indicates the presence of phospholipids.

\section{Results and Discussions}

The 24 yeast isolates which were isolated from Surat sampling sites by dilution and plate techniques, 6 were from Kantiyajal, 4 were from Mandroi, 2 were from Mirzapur, 5 from Hazira and 5 were from Machhad sampling site. They were further screened 
for their biosurfactant activities and morphological characterization. Morphological characteristics of isolated yeasts shown in Table 2. All isolates shows round shape, smooth surface texture and entire margin. Six isolates gave alcoholic order and other all gave acidic. 11 isolates shows white pigmentation, 12 isolates shows off white pigmentation and only one isolate Ky-48 shows orange pigmentation, which isolated from Kantiyajal soil sample.

Table 2. Morphological characterization of yeasts isolated from mangrove areas of Surat region of Gujarat

\begin{tabular}{|c|c|c|c|c|c|c|c|c|c|}
\hline $\begin{array}{l}\text { Sampling } \\
\text { Sites }\end{array}$ & Isolates & Size & Shape & Elevation & Opacity & Odor & Pigment & $\begin{array}{l}\text { Surface tex- } \\
\text { ture }\end{array}$ & Margin \\
\hline \multirow{7}{*}{ Kantiyajal } & $\mathrm{Ky}-42$ & Small & Round & Convex & Opaque & Alcoholic & White & Smooth & Entire \\
\hline & $\mathrm{Ky}-43$ & Small & Round & Convex & Opaque & Acidic & Off white & Smooth & Entire \\
\hline & Ky-44 & Big & Round & Convex & Opaque & Acidic & Off white & Smooth & Entire \\
\hline & Ky-45 & Pin point & Round & Flat & Opaque & Acidic & Off white & Smooth & Entire \\
\hline & $\mathrm{Ky}-46$ & Pin point & Round & Convex & Opaque & Acidic & Off white & Smooth & Entire \\
\hline & Ky-47 & Big & Round & Capitate & Opaque & Acidic & White & Smooth & Entire \\
\hline & Ky-48 & Small & Round & Convex & Opaque & Acidic & Orange & Smooth & Entire \\
\hline \multirow{4}{*}{ Mandroi } & Ку-49 & Big & Round & Capitate & Opaque & Acidic & White & Smooth & Entire \\
\hline & Ky-50 & Pin point & Round & Flat & Opaque & Alcoholic & Off white & Smooth & Entire \\
\hline & Ky-51 & Pin point & Round & Flat & Opaque & Acidic & Off white & Smooth & Entire \\
\hline & Ky-52 & Small & Round & Convex & Opaque & Acidic & Off white & Smooth & Entire \\
\hline \multirow{2}{*}{ Mirzapur } & Ky-53 & Small & Round & Flat & Opaque & Acidic & Off white & Smooth & Entire \\
\hline & Kу-54 & Small & Round & Convex & Opaque & Acidic & White & Smooth & Entire \\
\hline \multirow{5}{*}{ Hazira } & Ky-55 & Big & Round & Capitate & Opaque & Acidic & White & Smooth & Entire \\
\hline & Ky-56 & Pin point & Round & Flat & Opaque & Acidic & Off white & Smooth & Entire \\
\hline & Ку-57 & Small & Round & Convex & Opaque & Alcoholic & White & Smooth & Entire \\
\hline & Ky-58 & Pin point & Round & Flat & Opaque & Acidic & Off white & Smooth & Entire \\
\hline & Ky-59 & Small & Round & Convex & Opaque & Alcoholic & White & Smooth & Entire \\
\hline \multirow{6}{*}{ Machhad } & Ky-84 & Pin point & Round & Flat & Opaque & Acidic & Off white & Smooth & Entire \\
\hline & $\mathrm{Ky}-85$ & Big & Round & Capitate & Opaque & Acidic & White & Smooth & Entire \\
\hline & Ky-86 & Small & Round & Convex & Opaque & Alcoholic & White & Smooth & Entire \\
\hline & Ky-87 & Small & Round & Convex & Opaque & Acidic & White & Smooth & Entire \\
\hline & Ky- 88 & Small & Round & Convex & Opaque & Alcoholic & White & Smooth & Entire \\
\hline & Ky-89 & Pin point & Round & Flat & Opaque & Acidic & Off white & Smooth & Entire \\
\hline
\end{tabular}

Total 24 isolates were used further for screening of extracellular biosurfactant production grown on Kitamoto's medium containing cottonseed oil as source of carbon. Cell biomass increased throughout the process for all of the different isolates. Among 24 yeast isolates, Isolate Ky-46 shown highest dry cell biomass weighted $6.2 \mathrm{~g}$ after incubation period.

All these isolates were screened for biosurfactant production by 1) Parafilm M test 2) Oil displacement method 3) Emulsification index method. Out of 24 isolates, 6 isolates shown biosurfactant activity whereas isolates from Hazira and Mandroi did not show any biosurfactant activity ( Table 3 ). These six isolates had shown positive result for Parafilm-M test, where maximum diameter of drop shown by Ky-46 $(0.7 \mathrm{~cm})$ followed by Ky-53 $(0.6 \mathrm{~cm})$, Ky-54 $(0.6 \mathrm{~cm})$ and Ky-84 (0.6 cm) and Ky-86 (0.5 $\mathrm{cm}$ ) ( Figure 1). All six isolates had shown positive results for Oil spreading method. The displaced zone for Ky-46 had shown maximum displaced area with a diameter of $4.0 \mathrm{~cm}$ ( Figure 2). Five isolates shown the clear zone which ranged between $1 \mathrm{~cm}$ and $3 \mathrm{~cm}$, three isolates produced the clear zone with less than $1 \mathrm{~cm}$ diameter while the remaining fifteen isolates did not show any detectable clear zone ( Table 3). 


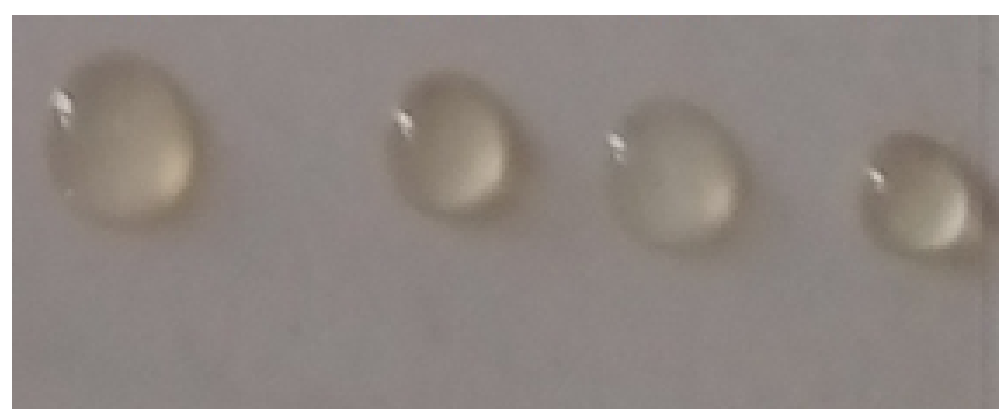

Fig 1. Parafilm M Test for biosurfactant production by selected yeast isolates. Parafilm M tests of isolates Ky-46, Ky-59, Ky-86 andControl (Cell free sterile fermentative media)

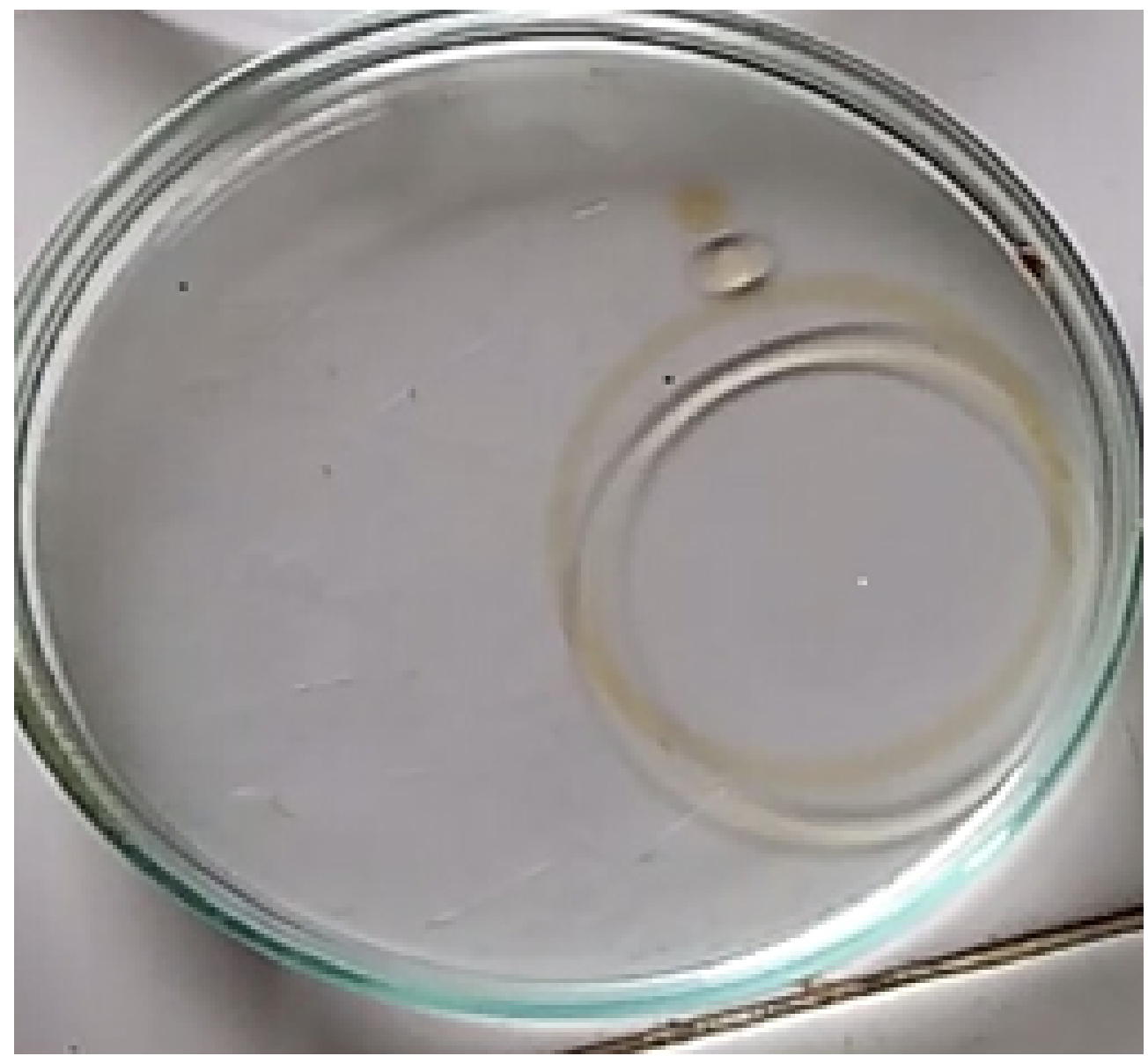

Fig 2. Oil displacement shown due to the production of biosurfactant by yeast isolate Ky-46. The clear zone formation on crude oil by biosurfactantproduced by isolate Ky- 46

The biosurfactant activity of selected Ky-46, Ky-53, Ky-54, Ky-84, Ky-86 and Ky-87, were evaluated by Emulsification index method. The emulsification index of these isolates were determined and calculated after $24 \mathrm{~h}$ of incubation. The highest emulsification index was formed by Ky-46(61.53\%), indicates a good biosurfactant production ( Figure 3). As per the results observed isolate Ky-46 from Kantiyajal soil sample shown maximum biosurfactant production. 


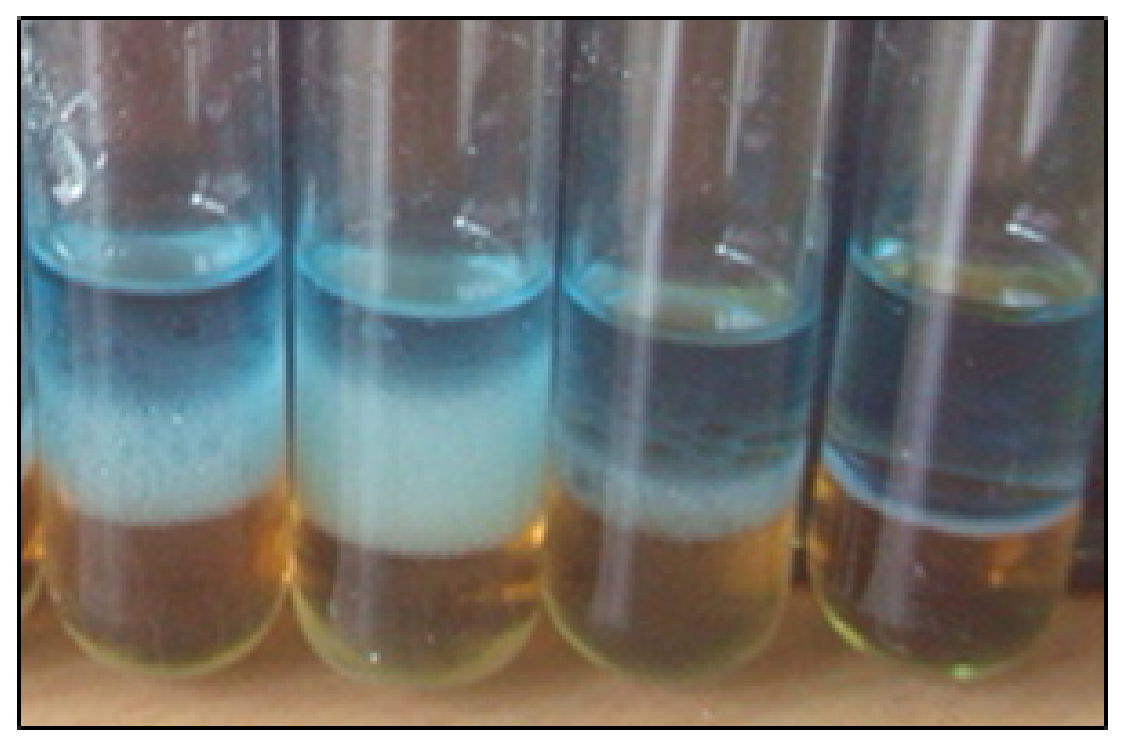

Fig 3. Emulsion layer formed due to biosurfactant production by Yeast isolates. Emulsion layer formed by Yeast isolates Ky-86,Ky-46, Ky-59 and Control (Cell free sterile fermentative media)

Table 3. Screening of yeast isolates for the production of biosurfactant

\begin{tabular}{|c|c|c|c|c|}
\hline Sampling Sites & Yeast Strains & Parafilm M test & Oil Displacement activity & Emulsification index (E 24) \\
\hline \multirow{7}{*}{ Kantiyajal } & ky-42 & - & - & - \\
\hline & $\mathrm{ky}-43$ & - & - & - \\
\hline & $\mathrm{ky}-44$ & - & - & - \\
\hline & $\mathrm{ky}-45$ & - & - & - \\
\hline & ky-46 & 0.7 & 3.5 & 61.53 \\
\hline & ky-47 & - & - & - \\
\hline & $\mathrm{ky}-48$ & - & - & - \\
\hline \multirow{4}{*}{ Mandroi } & ky-49 & - & - & - \\
\hline & $\mathrm{ky}-50$ & - & - & - \\
\hline & $\mathrm{ky}-51$ & - & 0.7 & - \\
\hline & ky-52 & - & - & - \\
\hline \multirow{2}{*}{ Mirzapur } & ky-53 & 0.6 & 2.0 & 37.03 \\
\hline & ky-54 & 0.6 & 1.5 & 33.33 \\
\hline \multirow{5}{*}{ Hazira } & ky-55 & - & - & - \\
\hline & ky-56 & - & - & - \\
\hline & ky-57 & - & - & - \\
\hline & ky-58 & - & - & - \\
\hline & ky-59 & - & - & - \\
\hline \multirow{6}{*}{ Machhad } & ky-84 & 0.6 & 2.5 & 39.28 \\
\hline & ky-85 & - & 0.5 & - \\
\hline & ky-86 & 0.6 & 3.0 & 46.66 \\
\hline & ky-87 & 0.5 & 1.5 & 33.33 \\
\hline & ky-88 & - & - & - \\
\hline & ky-89 & - & - & - \\
\hline
\end{tabular}

In Parafilm M test, Oil displacement test andemulsification method (-) indicates negative activity.

Phenol-Sulfuric test, Biuret test and Phosphate test were performed with cell-free supernatant of all selected six isolates to 
identify type of biosurfactant produced. All six yeasts showed positive result for Phenol Sulfuric acid test and negative result for Biuret test and phosphate test. Hence the biosurfactant produced by all six yeasts was classified as a glycolipid. Most known biosurfactants are glycolipids ${ }^{(8)}$. Rhamnolipids, Sophorolipid and trehalolipids are best known glycolipids ${ }^{(5)}$.

The use of low cost and viable carbon source is necessary to produce commercially viable product with minimum cost ${ }^{(21)}$. The renewable sources like waste olive oil, palm oil, sunflower oil etc are the best option to reduce substrate cost ${ }^{(22)}$. Hence, cotton seed oil was used in the present study for biosurfactant production from the mangrove yeasts. Biosurfactant production from cottonseed oil was previously studied by Luna et al., 2009 ${ }^{(7)}$. The Parafilm M test is indicative test of the surface activities and oil spreading technique is reliable method to detect biosurfactant production by microorganism ${ }^{(22)}$. The diameter of clear zone formed by supernatant which containing biosurfactant has been directly proportional to the concentration of biosurfactant produced ${ }^{(23)}$. Candida glabrata shows $66 \%$ emulsification index by using cotton seed oil ${ }^{(7)}$. Emulsification index of the biosurfactant from Trichosporon asahii was measured as $89 \%$ by using diesel oil as a substrate ${ }^{(24)}$. Where as in the present study biosurfactant production by Ky-46 found near to biosurfactant produced by Candida glabrata and lower than biosurfactant produced by Trichosporon asahii. According to result of Parafilm M test, Oil displacement method and Emulsification index method, Ky-46 yeast shows maximum biosurfactant production.

\section{Conclusion}

Biosurfactant producing yeasts are naturally presents in soils. The present study was undertaken to isolate yeasts from soil of five different mangrove sites of Surat region and then screened for the production of biosurfactant using cotton seed oil as a substrate. Total 24 yeasts were isolated from different soil samples. They were further screened for biosurfactant activities by Parafilm M test, Oil displacement method and Emulsification index method. Six yeast strains namely Ky- 46, Ky-53, Ky-54, Ky84, Ky-86 and Ky-87, shown positive results in all biosurfactant screening tests. Among all yeast strains Ky-46 shown highest activities in Parafilm M test $(0.8 \mathrm{~cm})$, Oil displacement method $(4.0 \mathrm{~cm})$ and emulsification index $(61.53 \%)$ followed by isolate Ky-86 in Parafilm M test $(0.6 \mathrm{~cm})$, Oil displacement method $(3.0 \mathrm{~cm})$ and emulsification index (46.66\%). The biosurfactant produced by these isolates was Glycolipid in nature, confirmed by Phenol-Sulfuric acid method. Large scale production of biosurfactants recommended for further study by using agro industrial waste as a substrate.

\section{Acknowledgment}

Authors are grateful to the Department of Biotechnology and Microbiology, Shri M.M. Patel Institute of Sciences and Research of Kadi Sarva Vishwavidyalaya, Gandhinagar for providing necessary facilities for the execution of the present work.

\section{References}

1) Mnif I, Elleuch M, Chaabouni SE, Ghribi D. Bacillus subtilis SPB1 biosurfactant: Production optimization and insecticidal activity against the carob moth Ectomyelois ceratoniae. Crop Protection. 2013;50(1):66-72. Available from: https://dx.doi.org/10.1016/j.cropro.2013.03.005. doi:10.1016/j.cropro.2013.03.005.

2) Saharan B, Sahu R, Sharma D. A Review on Biosurfactants: Fermentation, Current Developments and Perspectives. Genetic Engineering and Biotechnology Journal. 2011;2011(1).

3) Banat I, Thavasi R, Jayalakshmi S. Biosurfactants from marine bacterial isolates. 2011. Available from: https:/pure.ulster.ac.uk/en/publications/ biosurfactants-from-marine-bacterial-isolates-3.

4) Zajic JE, Guignard H, Gerson DF. Properties and biodegradation of a bioemulsifier from Corynebacterium hydrocarboclastus. Biotechnology and Bioengineering. 1977;19(9):1303-1320. Available from: https://dx.doi.org/10.1002/bit.260190905. doi:10.1002/bit.260190905.

5) Ilori MO, Amund DI. Production of a Peptidoglycolipid Bioemulsifier by Pseudomonas aeruginosa Grown on Hydrocarbon. Zeitschrift für Naturforschung C. 2001;56(7-8):547-552. Available from: https://dx.doi.org/10.1515/znc-2001-7-812. doi:10.1515/znc-2001-7-812.

6) Ilori MO, Amobi CJ, Odocha AC. Factors affecting biosurfactant production by oil degrading Aeromonas spp. isolated from a tropical environment. Chemosphere. 2005;61(7):985-992. Available from: https://dx.doi.org/10.1016/j.chemosphere.2005.03.066. doi:10.1016/j.chemosphere.2005.03.066.

7) de Luna JM, Sarubbo L, de Campos-Takaki GM. A new biosurfactant produced by Candida glabrata UCP 1002: characteristics of stability and application in oil recovery. Brazilian Archives of Biology and Technology. 2009;52(4):785-793. Available from: https://dx.doi.org/10.1590/s1516-89132009000400001. doi:10.1590/s1516-89132009000400001.

8) Desai JD, Banat IM. Microbial production of surfactants and their commercial potential. Microbiology and molecular biology reviews : MMBR. 1997;61(1):47-64. Available from: https://dx.doi.org/10.1128/.61.1.47-64.1997. doi:10.1128/.61.1.47-64.1997.

9) Kosaric N. Biosurfactants in industry. Pure and Applied Chemistry. 1992;64(11):1731-1737. Available from: https://dx.doi.org/10.1351/pac199264111731. doi:10.1351/pac199264111731.

10) Jain RM, Mody K, Joshi N, Mishra A, Jha B. Production and structural characterization of biosurfactant produced by an alkaliphilic bacterium, Klebsiella sp.: Evaluation of different carbon sources. Colloids and Surfaces B: Biointerfaces. 2013;108:199-204. Available from: https://dx.doi.org/10.1016/j.colsurfb. 2013.03.002. doi:10.1016/j.colsurfb.2013.03.002.

11) da Silva ACS, dos Santos PN, e Silva TAL, Andrade RFS, Campos-Takaki GM. Biosurfactant production by fungi as a sustainable alternative. Arquivos do Instituto Biológico. 2018;85(0). Available from: https://dx.doi.org/10.1590/1808-1657000502017. doi:10.1590/1808-1657000502017. 
12) Cameron DR, Cooper DG, Neufeld RJ. The mannoprotein of Saccharomyces cerevisiae is an effective bioemulsifier. Applied and Environmental Microbiology. 1988;54(6):1420-1425. Available from: https://dx.doi.org/10.1128/aem.54.6.1420-1425.1988. doi:10.1128/aem.54.6.1420-1425.1988.

13) Cooper DG, Paddock DA. Production of a Biosurfactant from Torulopsis bombicola. Applied and Environmental Microbiology. 1984;47(1):173-176. Available from: https://dx.doi.org/10.1128/aem.47.1.173-176.1984. doi:10.1128/aem.47.1.173-176.1984.

14) Fontes GC, Amaral PFF, Coelho MAZ. Produção de biossurfactante por levedura. Química Nova. 2008;31(8):2091-2099. Available from: https://dx.doi. org/10.1590/s0100-40422008000800033. doi:10.1590/s0100-40422008000800033.

15) Der WJV. Methods for the isolation, maintenance, classification and identification of yeasts. In: van Rij NJWK, et al., editors. The Yeasts Taxonomic Study. 1984;p. 45-105.

16) Kitamoto D, Haneishi K, Nakahara T, Tabuchi T. Production of mannosylerythritol lipids by Candida antarcticafrom vegetable oils. Agricultural and biological chemistry. 1990;54(1):37-40. Available from: https://doi.org/10.1271/bbb1961.54.37.

17) Kalyani AL, Naga SG, Aditya AK, Girija S. Isolation and antimicrobial activity of rhamnolipid (biosurfactant) from oil-contaminated soil sample using humic-acid salts-vitamin agar. International Journal of Research in Engineering and Technology. 2014;3(5):357-365.

18) Morikawa M, Daido H, Takao T, Murata S, Shimonishi Y, Imanaka T. A new lipopeptide biosurfactant produced by Arthrobacter sp. strain MIS38. Journal of Bacteriology. 1993;175(20):6459-6466. Available from: https://dx.doi.org/10.1128/jb.175.20.6459-6466.1993. doi:10.1128/jb.175.20.6459-6466.1993.

19) Satpute SK, Banpurkar AG, Dhakephalkar PK, Banat IM, Chopade BA. Methods for investigating biosurfactants and bioemulsifiers: a review. Critical Reviews in Biotechnology. 2010;30(2):127-144. Available from: https://dx.doi.org/10.3109/07388550903427280. doi:10.3109/07388550903427280.

20) Kalyani A, Sireesha GN. Isolation of bio-surfactant producing actinomycetes from terrestrial and marine soils. International journals of Pharmaceuticals Sciences and Research. 2014;5(9):4015-4022. Available from: http://dx.doi.org/10/13040/IJPSR.0975-8232(9).

21) Mukherjee S, Das P, Sen R. Towards commercial production of microbial surfactants. Trends in Biotechnology. 2006;24(11):509-515. Available from: https://dx.doi.org/10.1016/j.tibtech.2006.09.005. doi:10.1016/j.tibtech.2006.09.005.

22) Vijaya B, Jayalakshmi NR, Manjunath K. Enumeration of biosurfactant producing microorganisms from oil contaminated soil in and around Bangalore (India). International Journal of Current Science. 2013;5:86-94.

23) Ianieva O. 2013. Available from: http://nbuv.gov.ua/UJRN/MicroBioll_2013_75_4_10.

24) Chandran PR, Das N. Biosurfactant production and diesel oil degradation by yeast species Trichosporonasahii isolated from petroleum hydrocarbon contaminated soil. International Journal of Engineering Science and Technology. 2010;2(12):6942-53. 